\title{
From Unparalleled "Greatness" to Predictable Insularity. A Composite Sketch of "Warped Britishness" as Drawn in Selected Works of Contemporary English Fiction
}

Five years after the Brexit vote, the public domain is still filled with doubts, even anxieties, concerning the projections of a post-Brexit world. Given Benedict Anderson's thoughts on communities in transition, it is of no surprise that different social/cultural/political dilemmas have led to attempts at (de)constructing the "core" of national identity. "What is the state of the United Kingdom?" asks Daniel Wincott (15), implying that, with regard to the wide context of Brexit, it can be construed either in terms of a looming crisis or a major watershed. Faced with this quandary, a number of academics and writers in the British Isles have tried to touch for truths, half-truths, manipulations, and sometimes deliberate lies: all of which have been circulated with the intent of making people recognize the state's (non-)sovereignty as well as its suppressed cultural distinctiveness (Nedergaard and Henriksen 134). The latter issue also becomes a crucial point of reference in Francis Fukuyama's analysis of the reasons for unleashing a nationwide "enthusiasm" to leave the European Union. Seen from his perspective, the Brexit campaign did not look much different from other political agendas that prefer erecting "walls" instead of building bridges. According to him, it was the question of a unique "identity" that came to the fore in the first place for "many Leave voters." And their skepticism, to put it euphemistically, towards a cross-continental camaraderie (which they perceived as a step backwards down the evolutionary ladder) stemmed directly from "a long-standing belief 
in English exceptionalism" (Fukuyama 152). While the factors leading to Brexit were myriad, it was the need for the aforementioned distinctiveness, attached to the concept of Britishness/Englishness, ${ }^{1}$ that revealed its discordant potential and set the country "ablaze."

Regarding the above, the country's strategic choice to terminate a tight alliance with mainland Europe has, in fact, enhanced the appeal of binary divisions. The decision to leave boiled down, inter alia, to a straightforward conviction that the core identity had been diluted by "others," and the 2016 referendum provided a great opportunity to regain a hold over Britain's cultural, social and political heritage. ${ }^{2}$ Therefore, it would be both vital and interesting to juxtapose people's trust in the glorious past and British/English exceptionality with more sobering literary projections of a new post-Brexit world. In order to discuss the consequences of this self-inflicted condition, I will here elaborate on selected literary texts. Although the chosen works of fiction will be invoked and analyzed in greater detail later on, yet for the clarity of the argument, it seems crucial to enumerate them the way they have been laid out in this paper. The examination begins from England, England by Julian Barnes, then with a substantial shift in timeline, the other four novels are studied, namely The Lie of the Land by Amanda Craig, Autumn by Ali Smith, The Cockroach by Ian McEwan, and finally Alice in Brexitland by Lucien Young. Barnes' narrative was written much earlier than 2016, yet it has been chosen for its adequate portrayal of a model projection of Englishness. The other four novels, already issued in the wake of the plebiscite, feature authors who draw conclusions running parallel

1 Of utmost importance is the question whether to use those two terms interchangeably in the following discussion on the process of post-Brexit identity formation. According to Christopher Browning (224), the divorce from the $\mathrm{Eu}$ forwarded the need to "establish a sense of ... continuity by cultivating narratives of self-identity that locate" subjects in separation from their political ex-spouses. Yet, as underlined by Jack Black, the 2016 referendum can be analyzed in the context of English nationalism (192). Ultimately, "the blame" cannot be put on the entire United Kingdom. Similarly, Stefan Berger points out that, with reference to the aforementioned narratives of national formation, one should bear in mind that "the practice of British[ness] ... remains Anglocentric" (670). Therefore, paraphrasing Richard Bradford, the paper examines some general tendencies in (re)constructing collective identity, with the emphasis put on selected works of fiction wherein it is "Englishness" rather than Britishness that operates "as the organizing principle" (92).

2 According to Francis Fukuyama, right-wing politicians in particular had been fanning the flames of resentment (if not hostility) towards immigrants, who were held responsible for "eroding long-established cultural identities" (7). 
to Anderson's assumptions that in times of crisis a general predilection for self-deluding (re)constructions of collective identity can be observed, which are variously expressed in a merely referential, subversive or satirical manner.

As indicated earlier, at least some of the literati have understood that on novelists lies the onus to debunk the fallacy of the Manichean contest between a genuine/distinct Englishness and an "inessential" Europeanness. Lyndsay Stonebridge, in her article "The Banality of Brexit," paraphrased Hannah Arendt to underline that writers ought not to remain dormant and needed to respond to the "tectonic shift" taking place in the Isles. Literature was to "offer the antidote to banality" (11), albeit not to that of evil but that of Brexit. The "leave" decision, in this regard, has been attributed to celebrated ignorance, which eventually "unleashed hatred and intolerance" (8-9). Under such circumstances, writers could not avert their eyes from morals. ${ }^{3}$ In other words, as indicated by Kristian Shaw, the literary field is by all means called to take a stance, particularly when the vote has reopened the door to divisive tendencies. By dismissing "the European project, [which] tries to reconcile national tensions" (22), the Brexiteers have let the djinn out of its bottle. ${ }^{4}$ As Shaw underlines, "literature has always been a significant influence on the perception of [collective identity]" (18), but now, in post-Brexit contexts, it seems more pressing than ever before to make writers explore any (de)formative rifts within the social fabric.

The imaginary that enables us to prompt "more nuanced readings of the Brexit vote," needs to be accompanied by other "texts ... of [social, political and cultural] resonance ... that shape a discourse surrounding issues of [English identity]" (Upstone 46-47). In relation to this, Bryan Cheyette expresses his skepticism towards the functionality of national homogeneity, and he shows how Brexit enhanced "the illusion ... that there are no other futures than the nation-state for the United Kingdom or Great Britain" [emphasis added] (69). That (in)advertently heralds a turn towards the past, when the English (allegedly) shared a "sense of exceptionalism" that made them "proud of standing alone and apart" (Docherty 182, 187). Following pre-Brexit/post-Brexit discourses,

3 Paraphrasing Oscar Wilde, the morality of prose writing consists in delving into debates on matters of social/cultural/political resonance. It should be noted, however, that the above wording does not go so far as to suggest that writers should position themselves as guardians of religiously-construed morality.

4 Shaw finds a perfect illustration of this problem in Ali Smith's book Autumn, wherein the following passage speaks volumes about the potential ramifications of Brexit (Shaw 22): "Rule Britannia .... First we'll get the Poles. And then we'll get the Muslims. Then we'll get the gyppos, then the gays" (Smith 197). 
then, one observes a tendency to spin the mirage of a regained, self-sufficient state again able to rely on its unprecedented cultural, economic and political heritage. In a similar vein, Afua Hirsch writes how the public debate has become dominated by narrative attempts to rebuild and consolidate the idea of national uniqueness. According to her, what feeds a pro-Brexit state of mind is "nostalgia [that] afflicts not only the white working class, but unites ... politicians and the middle classes." What it designates comes down to "a sentiment [which reveals] its potent force, appeal[ing] to an imperial past and an immigration-free future, [thus] a fantasy that never did, and never will, exist"s (271). No matter how delusional it may be, the advocates of separation stress that a reaffirmation of the national identity in its traditional form is possible on the condition that the "quintessential" traits of Englishness are retrieved.

From reading the above arguments, I contend that it becomes of crucial importance to ponder the question of certain "initial positions" 6 that laid the foundations for the "unquestionable" format of Englishness. Stefan Berger diagnoses the presence of what he deems "heritage mania" and observes it having gained momentum particularly in the 1990s. The main idea behind such debates was "an attempt to rebuild an English tradition without ruptures and discontinuities" (655). Nonetheless, Berger's study provides a clear indication that such paradigmatic schemes of national (dis)integration were subject to critical reflection. This should not surprise, given Stuart Hall's general view on identity building. As Hall claimed, any identity formation is always a process during which constant reevaluations of cultural notions take place. This, in turn, must lead to a general mistrust towards any hermetic notions impeding individual or collective identity formation. A different/opposing scenario entails no room for "the significant breaks", as "[no] old lines of thought are disrupted, [no] older constellations displaced, and [no] elements, old and new, regrouped around a different set of premises and themes" (664). With this stipulation in mind, one realizes that the aforementioned attempts to restore an uninterrupted essence of Englishness have not been utterly disavowed. Nothing testifies so convincingly to the resonance of such sentiments than the impact they had on the public by

5 Daphne Kapsali, in her book Divided Kingdom. How Brexit Made Me an Immigrant, points out that the discursive space in which Britishness/Englishness is being reimagined relates to "a time before, that can never be recreated," as it only tries to resurrect "the ghost of Great Britain" (20).

6 Although it is set against a different national context, Serhii Bilenkyi's analysis, in which he underlines the importance of idioms of nation-ness that signify the above-mentioned initial positions, is worth mentioning (103-4). 
the end of the first and the beginning of the second decade of the twenty-first century. It suffices to note with what intensity people began to reiterate slogans concerning regaining control over their lives, institutions and, most importantly, their identity as well as a sense of (un)belonging. ${ }^{\text {? }}$

Jack Black reads the dynamic of hyper-identification with the national paradigm in terms of emotional experiences that have congealed into a general "mood," which strongly resonates among local communities. Mindful of the tone of various discussions, it becomes clear that the scope of what is to define Englishness has been narrowed down to those identity markers which are firmly entrenched in the 'glorious' past. Paraphrasing Jon Stratton, any "other" identities, dependent upon cultural, social or political "liquidity" (after Bauman), could be pushed aside by the general validation of "a mythic ... homogenous past" (232). In other words, one looks all the way back to those times when an "untransformed" society enabled people to cherish English identity in its purest form. Christopher Browning corroborates the persistence of these ideas. In his studies over certain reactionary tendencies within the (post-)Brexit realm, he asserts that such a nostalgic trend relates to the past being "idealized," but also "entails a critique of the present and a future vision, dangl[ing] a fantasy of the recovery of that which was lost" (231). Evidently, in order to proclaim a new/reformed cultural and socio-political reality of the United Kingdom, it becomes necessary to restore the validity of "patriotic rhetoric." How wrong were those who hoped that it had receded into history due to such vectors of policy-making having seemed discordant with the dynamics of multicultural/ pan-European identity formation.

What are, then, some of those idioms of Englishness that echo some former distinctions of the national identity? As indicated by Susan Condor and Steve Fenton, Britain's collective imagination has recently again been subjugated

7 Tristan de Bourbon-Parme, a foreign correspondent in Great Britain working for $\mathrm{La}$ Libre Belgique and La Tribune de Genève, reported on post-Brexit sentiments in the following way: "[d]uring the referendum campaign, discourse pivoted on control, lost and (re)gained. 'Control' had the power to extract the country from the jurisdiction of the European Court of Justice. 'Control' could put an end to the competition posed by European migrants for access to employment, ... schools, and the wage stagnation generated by the arrival in lower skilled jobs. ... 'control' would expose the social injustices of economic growth benefiting only Metropolitan centers, while peripheral cities, villages and neighborhoods suffered from impoverishment" (31).

8 Black elaborates on the overshadowing spirit of English nationalism, minding Arthur Aughey's distinction between "a mood" and "a movement" which eventually contributed to leaving the Union (192). 
to a myth-making belief that in the good old days "people possessed a stable, clear, unambiguously positive sense of English identity" (390). Its constituent elements, which pertain to the notion of "national essentiality," appear to have an off-the-cuff character. The past, as the key factor, is inscribed into a set of grand (mostly political) narratives marked by "the legacies of empire" (Heidemann 2). In this regard, a broader spectrum of high-minded ideas-such as political/ military strength, economic and cultural expansion, and the imperial spreading of Western values across the globe-have come to the fore. That historical perspective, however, is too sanguine, as it deflects from shedding a grimmer light on the notion of Englishness. This is particularly the case when we read of an articulation of British policies as being drawn upon "the centrality of identity conflicts," with a focus on "assertive and ethnically exclusive nationalism" characterized by "hostility to migrants and minorities"9 (Sobolewska, Ford 331). What is at issue, then, is the angle from which the English want to see themselves. According to patriotic rhetoric, only by (re)directing attention to the "imaginary elements" rooted in the bygone can a direct route to "fulfillment" be found (Browning 230). As Richard Bradford rightly notices, a certain realm of narrative possibilities has thereby been created under the auspices of which "the emotional mythology of being English" (93) has been acted out in the Leavers' campaign. ${ }^{10}$

Amidst the aforementioned idioms of collective identification, there are ideas and concepts mainly revolving around "fantasies of past power and glory, and splendid isolation" (Mishra 274). It is crucial to notice that the project of combining the new with the old derives from the narrowing dynamics of national(ist) discourse. Sadly, a similar cultural and political phenomenon, which seems to have a wide-ranging character, has recently been spreading across half of the modern world. Its ramifications are visible in the present-day United Kingdom. According to Mishra, the recent formula of nationalism/national identification is not much different from what it denoted a century ago. Both then and now, its advocates knew (know) what they need(ed), namely "the

9 Worth noting, especially in the context of other essays in this volume, is that such tendencies of political populism are observable not only in Great Britain, but also across Europe and the United States (Sobolewska, Ford 331).

10 The above term "Leavers" has been used on purpose to underline that the general mindset of separateness cannot be only attributable to the political elites, but also to the country's ordinary men and women, who share " $[\mathrm{t}]$ he nostalgic idea that the Commonwealth would rise out of the ashes of Britain's trading relationship with Europe and carry the nation back to this greatness." As underlined by Hirsch, that narrative "was powerfully compelling, and not just in the rhetoric of politicians, but among voters too" (270). 
means to establish and reinforce collective identity, to designate what "we" are like and how we differ from 'them"" (168). "Unlike "them," "we" have our glorious past, and it is evident that "we" need to "become the Britain we once were"12 (Boyle 28). This is redolent of the aforementioned desire for a return to the "places" that have been (re)constructed for (re)consolidation purposes. Interestingly, such a national framework is not only constituted on the glorious past, but also it is underpinned by the idea of Englishness as viewed through the lens of a romanticized landscape/way of life. An adequate illustration is provided by Stratton, who, by reference to Midsomer Murders, perceives the series' popularity as derived from the portrayal of an English countryside community whose characteristic trait is "racial and cultural homoge[neity]" (233). Such a world, which has its own integrity, demands different forms of celebration as well as a safeguard against the external threat associated with "immigration," which (for many) has become synonymous with "invasion" (235).13

Given what has been already outlined, it is legitimate to claim that Brexit prompted a shift in the collective mindset, which resulted in seeking authenticity through binary oppositions. The 2016 decision to bid farewell to the European Union demarcates a symbolic time-line beyond which the country is supposed to regain its political strength, historical pride, cultural vigor, national purity, and a sense of agency and sovereignty. As Fukuyama claims, the Brexit campaign convinced a sufficient majority that it was time for fundamental change, as "this country [was] no longer [theirs]." Yet every one of them is "a core member of [the] great nation," confronted with the "others," who by default "pose a threat to cultural identity" (89). Shrouded in a dense fog of the national(ist) rhetoric of integrity, today's Britain appears to be the home not for a great nation but rather a divided society. Some would like to put the blame on "the politicians [and their] thoughtlessness" (Stonebridge 9). Nonetheless, as underlined by

11 Let me invoke Zygmunt Bauman's view on how identities undergo the process of fossilization: "[o]ne is born a member of the tribe and one dies in the same capacity, putting on in the meantime and taking off again a series of strictly defined and non-negotiable identities in a strictly defined and non-negotiable succession" (1999: 162). Twenty years later, Sobolewska and Ford position the Brexit affair within global tendencies reflecting "ethnocentric 'us against them' conflicts over issues such as immigration, national identity and diversity" (326).

12 That is exactly what Edward Said had in mind, saying that various collectivities reveal the predilection to live by a "... constructed and maintained sense of place" (2000: 180).

13 Interestingly enough, in light of Brexit-mania, it comes as no surprise that "other" Europeans (from behind the Iron Curtain) are defined through "a way of life alien [sic!] to English culture" (Stratton 236). 
Shaw, there are ordinary citizens and "the inherent divisions within society" that led to the referendum. That plebiscite, held to give voice to the people, "was the manifestation of ... [decades-long] Euroscepticism, resistance to mass immigration ..., rage regarding the [economic] crisis, and the corresponding failures ... to acknowledge the values of modern patriotism" (16). According to Stonebridge, with society at a crossroads, it is the writer's obligation to counteract an insular and dogmatically politicized public discourse. In this sense, literature (as signaled before) is to "offer the antidote" to the possible ramifications of Brexit, and as such cannot abrogate the responsibility to "think harder about ... cultural and political belonging" (11). With this central quandary in mind, I will provide a critical insight into how the state of Englishness has been presented in selected (post-)Brexit literary works.

According to Upstone, in the wake of the popular vote, part of the local literary field started to orient itself towards producing "anthropologies of the future." ${ }^{14}$ With a more extended horizon in sight, novelists started to debate the present-day situation of Great Britain. Their narratives, in this regard, fit into a category of literary texts engaged in reflective commentaries upon the country's public domain. Heidemann points out that writings of the kind "may be read as contemporary versions of State-of-the-Nation novels or ... Condition-of-England novels that seek to sift out the socio-[political] divisions of their time" (4). Evident in the above context is the fact that the dynamics of Brexit writ large, and people's attitude to it, have had their imprint not only on individual mindsets, but also on the larger identity formations of the entire English population. Thus, the main idea is to find out whether contemporary literature opts for a validation of national separatism, or rather endorses a more dispersed identity that "accommodate[es] greater [European] diversity" (Einhaus 162). A potential response to that question I find in five selected works of contemporary English fiction. Such a limited range of primary sources, though lacking in comprehensive character, takes the (post-)Brexit reality as a frame of reference; therefore, it allows for a subjectively formulated, yet universalizing scholarly conclusion on (un)changing perceptions of Englishness.

Of the five novels mentioned above, one had already attracted notice several years before the 2016 plebiscite, and as such does not fall under the category of post-Brexit writing. England, England by Julian Barnes was published in the late 1990s, but even so, if briefly analyzed, its relevancy should not be questioned since it outlines the foundations for certain "myth-making" reflections on English grandiosity and uniqueness. As has been signaled elsewhere, a majority

14 Originally, that term was coined by Gabriele Schwab in her book Imaginary Ethnographies. 
of the voters share[d] a common vision which led them to believe they would be better off after the United Kingdom was divorced from the rest of Europe. Moreover, many tried to convince them that their sense of national pride and dignity would no longer be violated. Barnes' text, in a subversive way, illustrates at least some of the above arguments, and as such constitutes an insightful contrast/extra material to the anti-Brexit tropes observable in the remainder of the examined texts. It is often said that England, England pivots on a satirical representation of Britannia. But in truth, it would be a far-fetched conclusion to claim that the author, writing his "satirical" novel, aimed at backing a serious societal reform. Rather than delving into the intricacies of domestic relations, Barnes mainly mocked the idea of English essentialism. On the other hand, by highlighting the "fifty quintessences" of the great nation, he has advertently corroborated the significance of certain traditional pillars of English identity and collective imagination.

In order to extrapolate from Barnes' narrative and extend the applicability of his ideas to studying the strategic (dis)orientation of the English triggered (or completed) by the 2016 decision, I argue the validity of Browning's theoretical template, which examines the mechanism of "national fantasies." He equates the whole Brexit campaign and the very idea of this political divorce to "an empty signifier." It is so since the process of leaving the Eu has contributed, in a sort of paradoxical way, to creating a void to be filled only with acceptable parameters of collective identification. As Browning underlines, "Brexit became a concept, aspiration and demand into which various desires for redress and fulfilment could be channeled" (232). The term "redress" implies that people in the Isles, especially the pro-Leavers, at one point might have diagnosed the situation in their country as needing rectification. Theirs was resignation from the alliance with Europe, deliberately performed to cross the threshold beyond which lies, as they believe(d), a sense of genuine nation-ness. The novel, which enumerates some markers of such a traditional(ist) English identity pattern, perfectly predicts what sentiments the 2016 campaign might have evoked among the populace.

Within Barnes' patchwork of conceptual areas, certain thematic clusters are of minor socio-political resonance. However, there are other strands, highly informative as to what (allegedly) constitutes the core of Englishness. At the very top of that list is the "Royal family"; down the ladder of national essentiality are "Houses of Parliament," "Imperialism," the "Union Jack," "Winston Churchill," the "Battle of Britain," "Queen Victoria," the "Magna Carta"; and finally, some less politically-expressive signifiers, such as the "ввС," "Oxford/Cambridge," "Shakespeare" or the "Times Newspaper" (Barnes 83-85). Given Browning's 
assertion that Brexit at large is believed to guard against "chaos, crisis and ontological insecurity," and consequently offers a chance to "bring order, stability and control" (233), it is crucial to define how the conceptual framework could operate so as to temper vulnerability to the cultural, social and political concussions of the present. As indicated by Fukuyama, people under such circumstances face the question of "what country they are trying to take back" (133). Turning towards the past, they do not see, for instance, any crisis of the monarchy, but rather its authority and the glory in which the nation can bask. The country is seen through the lens of its long history, represented by the Royal Family. Its citizens should be proud of the deep-seated system of parliamentary democracy, as well as their imperial legacy, military and political prowess (Battle of England/Churchill/Queen Victoria), and legislative discretion (Magna Carta). Suffice to invoke, in the above context, Black's remark concerning the pro-Brexit voters, many of whom believe(d) that "the Empire is [not] gone, [and] still exists" (194). ${ }^{15}$ It is all set against the backdrop of a single story, ${ }^{16}$ where the English homeland "authenticates" fossilized cultural and political categorizations, which in turn are to essentialize the existence of a homogeneous society, under a (re) consolidated national tradition that demands recognition. ${ }^{17}$

Studying the other works, published immediately after the referendum, we have a chance to see how certain images elucidating the nuances of public life resonate sometimes in unison, but more often in contrast to the outlined background of an (un)folding English identity. Many claim that particularly economic factors made Brexit possible. Just as financial (in)stability can be regarded as having played a decisive role in the campaign, so too can other (immaterial) aspects be reckoned of ultimate importance in the final decision.

15 As Black rightly notices, the above reflects a general predilection of the public to "ignore the historical struggles embedded in England/Britain's past, in favor of one that present[s] a depiction of pre-Eu Britain as one of continuous stability" (203).

16 Darren Chetty writes about "the danger of a single story" with regard to modern practices of storytelling and their bearing on the "up-to-date" picture of contemporary Britishness. From his angle, what "limits the [collective] imagination," when it comes to defining the national format, is how persistently such narratives return the paradigm of a "white, middle-class, [and most importantly] English" person (99). Just as Chetty highlights the issue of inadequate representation, Barnes seems to have diagnosed the problem almost two decades earlier. The novelistic version of England, with its emblematic designates such as the "ввс," "Oxford/Cambridge," "Shakespeare," and the "Times Newspaper," relates to nothing else but the country's "self-constructed images and mythologies of its heritage" (Bradford 100).

17 Fukuyama, in the context of national identity formations, points out the presence of "a thymotic desire for recognition of one's dignity and status" (81). 
According to Sobolewska and Ford, the "focus" was two-fold, but it was nevertheless a question of "identity," with its strongly inflammatory potential, that snowballed into the Leave-movement (337). The blending of both elements is reflected in The Lie of the Land, a novel by Amanda Craig from 2017. This book provides a sketchy depiction of Great Britain, or more precisely a post-referendum England, as the country of internal conflicts. Mostly they are of an economic nature, yet the political factor is equally resonant. Bettina Schulz, ${ }^{18}$ referring to such overlapping domains, once said that "the British public will eventually realize that Brexit will not ... help with all the failures of domestic politics" (29). Nonetheless, Craig's narrative tells of individuals who deem the retreat from Europeanness a panacea for harm and exclusion. Interestingly, yet unsurprisingly, the main culprits for the "common" plight, who have lost themselves in the EU supranational identity, are the metropolitan elites: ${ }^{19}$

... the people at other tables: the young mothers, exhausted but still hopeful; the resting actors; the retired people whose pensions have not yet imploded; the joggers and dog-walkers. All around her are Londoners unaffected by what is being called "the current economic climate." They still drive big cars, go on foreign holidays, wear designer clothes and send their children to private schools. (Craig 21)

This is nothing but a cosmopolitan milieu, inhabited by men and women who are believed to have become the beachhead for a different, more elusive (non-British/non-English) tradition and identity. But, as Craig underlines in her novel, there are other constituent parts of the country, and they are by all means non-metropolitan. In this context, it is rather self-explanatory why she titled one of the chapters "This is England, too" (53).

The Lie of the Land illustrates the above dichotomy. On the one hand, there are those snug corners of the elite-like life, with its representatives allegedly detached from their roots; on the other, we have the salt of the earth, the genuinely English "provincial" communities. The latter tolerate immigrants, yet they are resistant to Europe due to a commonly shared conviction that some of the newcomers "take jobs and homes" from the natives (211). Heidemann

18 Bettina Schultz is a journalist, living in Britain since 1991. She first worked as a foreign financial correspondent for the Frankfurter Allgemeine Zeitung, and now writes for Die Zeit. Her field of expertise is economy and politics.

19 See Mishra's discussion of the gap between "disfranchised men" and "venal, ... mendacious elites" (76); or Browning's insistence on the division between "liberal elites" and "the nation's heartland" (227). 
quotes Craig who-when interviewed - ${ }^{20}$ highlighted "the rage" so many people felt thinking of the European Union (6). Although that friction between both identities develops in the background, the novel gives insight into how pro-Brexiteers define a potential remedy for the English malaise. Overall, it consists in the nation's revival of that which was. Today, as one of the characters says, "nobody cares"; therefore, most of "the Devonians" during "next election ... will vote for UKIP" (160). In the same vein, another representative of the countryside, in a conversation with a Londoner, gives vent to her frustration: “There are three generations of families who've grown up in Trelorn who can't get their kids school places, any more than you can get an appointment with the doctor. You want to know why we want to leave Europe? That's why" (216). As Sobolewska and Ford pointed out, it was David Cameron who feared that Brexit could "unleash demons" (248), such as xenophobia, Europhobia, isolationism, or societal fragmentations. All these negative phenomena could be accompanied by various formats of escapism. An interesting illustration of such a withdrawal is found in The Lie of the Land. In the countryside, people are to (re)discover what has been lost- " $\mathrm{t}]$ he English have made ... a fetish of country life that they believe it to be Heaven to which all good Englishmen and women should aspire" (203). This is the vision of Englishness that Black outlined in his article. Suffice it to invoke his claim that such an understanding of "England ... is widely nostalgic and deeply confident of a clear and distinguishable English feeling” (196).

A similar point of departure in describing the post-referendum landscape can be found in Autumn by Ali Smith, with the only difference being that it sketches out the clash between the Leavers and Remainers without any sentimental rhetoric. Bluntly put, Smith's narrative frames the study of a disconcerting sense of Englishness. Her understanding of collective identity, addressed in the aftermath of the referendum, indicates that the historical and cultural heritage discussed above has been voided of its original ideals. Paraphrasing Kapsali, Britain has turned into "the Divided Kingdom" that, as a matter of fact, perplexes people as to "where [they] stand" in terms of values (12). From this angle, I argue that Smith depicts a society whose fabric has been thrown into disarray. On the surface, there are two factions perfectly capable of expressing their pro-Brexit/anti-Brexit agendas:

Across the country, people felt it was the wrong thing. All across the country, people felt they'd really lost. All across the country, people felt

20 See Bridget Galton—“Amanda Craig: 'Brexit Is a Lightning Rod for Rural People"' 3 July 2017. https://tinyurl.com/y3xzwm72. 
they'd really won. ..., people felt they'd done the right thing and other people had done the wrong thing. All across the country, ... people felt unsafe. ..., people felt legitimized. ..., people felt bereaved and shocked. ..., people felt righteous. ..., people felt history at their shoulder. ..., people felt history meant nothing. ..., people threatened other people. ..., people told people to leave. ..., nobody spoke about anything else. ..., people said it wasn't that they didn't like immigrants. ... all across the country, the country was divided, a fence here, a wall there, a line drawn here, a line crossed there ... (Smith 60-61)

What resonates in the above excerpt, however, is "misery" rather than "rejoicing" (Smith 59). The former sentiments were adequately defined by Alan Hollinghurst, who recognized the ominous character of that fundamental change. Being forced to bid farewell to the core part of his identity, the writer expressed his exasperation in the following words: "We knew we belonged in Europe as our own country belonged there; all my adult life has been spent as a citizen of Europe as well as of Britain.... The mood, the madness, of our time is to destroy concord, cooperation, and as an inevitable result to destroy ourselves" (Hollinghurst 306). But others, as implied by Smith, feel the triumph to have been on their side, and their vision of quintessential Englishness to have gained in salience.

What distinguishing characteristic does this enhanced sense of English identity possess? The overall picture of post-Brexit sentiments, albeit situated somewhere in between the lines of Smith's story, presents a rather dismal prospect for a society tinged with antipathy toward diversified nationality. Fatigued by non-verbal violence inflicted upon "not us," Elisabeth's mother aptly elucidates the dilemmas of a Remainer: "I'm tired of the anger. I'm tired of the meanness $\ldots$ of selfishness. I'm tired of the violence there is and ... the violence that's on its way .... I'm tired of liars. ... I'm tired of lying governments .... I'm tired of being made to feel this fearful. I'm tired of animosity" (Smith 56-57). Both her mother and Elisabeth conclude in unison that they find it difficult to tolerate the new sense of collective identification. As Elisabeth relates, "people she passes on the streets ... regard ... each other with a new kind of loftiness" (54). This uplifting spirit, however, does not revivify the grand character of Britannia, yet it does show how dwarfed by their sheer resentment to "others" some of the English have become. When on a trip to her parental home, Elisabeth acts as a witness to how certain "patriots" addressed "the Spanish couple ... here on holiday." Waiting for a cab, she heard the natives "shout[ing] at them ... to go home. This isn't Europe" (130). She sees similar slogans- "GO HOME" (53), this time painted on the walls of different buildings-while walking through the 
village inhabited by her mother's neighbours. An interesting light is shed on the policy of resentment when Smith speaks through the voice of a radio guest. In defining the new/old nature of Englishness, his argument goes as follows: "it's not just that we've been rhetorically and practically encouraging the opposite of integration for immigrants to this country. It is that we've been ... encouraging ourselves not to integrate. We've been doing this ... since Thatcher taught us to be selfish" (111-112). Bradford, writing about Barnes' novel, pointed out that the novelist "brought nostalgia to life": nostalgia for a glorious heritage which had already "atrophied" (94). Studying a selection of post-Brexit literature, we may come to a similar conclusion that the legacy of this great nation has not just shriveled but been replaced with (in)significant and antagonistic self-delusions. ${ }^{21}$

Finally, two other texts of fiction serve as a literary critique of the post-Brexit self-complacency. Both Ian McEwan and Lucien Young seem to doubt whether such quintessential traits of the national character as common sense, reason and rationality can be still regarded as pertinent in defining the contours of Englishness. The Cockroach, a craftily rewritten version of Kafka's Metamorphosis, focuses - contrary to the latter work-on collective rather than individual mindset. It is worth noting that Kafka thematized, above all, the predicament of an individual man set against the vectors of nineteenth-century modernity. With no intent to question the teleological orientation of his world, Gregor Samsa felt estranged, like a cog in the machine. As indicated by Katarzyna Wigura, the protagonist underwent his upsetting change since he "did not fit in" the grand scheme of civilizational progress. McEwan's use of that transformative pattern is different as it frames a caricatural portrayal of the Brexiteers opposing reality, a distinctive feature of which is the decades-long cohabitation of Englishness and Europeanness. Central to this subversive text is the absurd policy of "Reversalism," which violates a supposedly English dictum of solid reasoning. Jim Sams, a new Prime Minister, gathers his "metamorphosed Cabinet," "a band of brothers and sisters," who strongly believe they are getting 'their country' back on the track of "normalcy":

They were precisely his own. Bound by iron courage and the will to succeed. Inspired by an idea as pure and thrilling as blood and soil. Impelled towards a goal that lifted beyond mere reason to embrace a mystical sense of nation, of an understanding as simple and as simply good and true as religious faith. (21-22)

21 Minding Fukuyama's terminology, one can define such self-centered and self-deluded representatives of the British/English populace as practicing "megalothymia," thus a "recognition of one's status as superior" (81). 
Arguably, inspired by the mood of religious fervor, they have understood that "nothing [can] stand in [their] way" (42), and stop them from forging a bright future for a reborn Great Britain.

Nevertheless, as McEwan anticipates, nothing but a crisis in international relations is likely to materialize. None of the European partners can rationally grasp the idea of "splendid isolation." Moreover, in response to the legitimate concerns about common partnership, Europeans expect "a nationalist wave of manufactured anger" (52). Hence the image of "Madame Chancellor" and her strenuous attempt to understand the reasons for redrawing and bringing to prominence some nebulous shapes of the past. In a dialogue with Jim Sams, she poses the most fundamental questions "Warum? ... Why are you doing this? Why, to what end, are you tearing your nation apart? Why are you inflicting these demands on your best friends and pretending we're your enemies?" The answer, given by the Prime Minister, was blunt- "[b]ecause. Because that's what we're doing. Because that's what we believe in.... Because. That, ultimately, was the only answer: because" [emphasis original] (86-87). They are doing this because that is what they pledged to do. As the reader is informed, "the origins of Reversalism are obscure," but one thing is certain, namely the notion of "purification by reversing" (25), which guarantees that the edifice of a rebranded Great Britain can be erected. This is the condition sine qua non for reaching "the promised land." Only in separation from continental Europe ${ }^{22}$ do the English have a chance to seek and (re)discover what is essential in their identity. For the reasons outlined above, I agree with Bradford, who defines contemporary "Englishness as a state of mind" and "a chimera" (96). On the basis of his claim, I would say that a majority of the populace, by collecting various bits and pieces, have constructed and customized to their liking a paradigmatic model of nationality. It is legitimate, then, to claim that in 2016 a considerable number of the voters embarked upon a journey to a place they have imagined.

But would it not be equally correct to see their peregrination as having a more ominous character, denoting an escapade into the unknown? Such seems to be the intent of Lucien Young's (alias Leavis Carroll) story Alice in Brexitland. From the onset of this intertextual response to Brexit, it becomes clear that "it was rarely very wise to go jumping down holes with no knowledge of where they might lead" (4). And yet, as could be expected, Alice (in her dream) as well as other Brexiteers (in reality) did jump. Evidently, one literary discourse here is "overlaid with meanings from another [socio-political] discourse" (Cuddon

22 Black indicates how the public was led (the present tense would do as well) to believe that they need(ed) to counteract "the expansion of the EU," which endorsed by corrupt "elites, in some form or another, ha[s] degraded English nationalism" (196). 
454). In this sense, the author deploys an alternative structure of signification that actually recapitulates some major discussion threads addressed hitherto in the paper.

The Brexitland Alice pays a visit to a sort of liminal place between the present and the past, or between reason and unreason. As she observes, a new dimension of patriotism is being forged here, which stresses (to use Sobolewska's and Ford's terminology) polarization on "identity grounds" (225). There are "us" and there are "others", and the blame is on the latter because they jeopardize, as Fukuyama indicated, "our" identity. And who could safeguard the "great nation" against that imminent threat better than Nigel Farage? The author uses the Cat character, a caricature of Farage, who is positioned to teach Alice "[t]he thing about them." The foreigners/the immigrants/the others, as the Cat clarifies, are "ruining this country. This is no longer the land I loved as a kitten. Great Britain used to be Great" (32). Another character, whose stance on national matters has been shaped by the "Daily Murdoch" is the Cock. On him and the like, as he perorates, lies the onus of responsibility to do something and restore the country to its former state: "All I'm saying ... is that we don't want foreigners flooding our forest and changing our way of life. [We need] to take back control and tell the frogs to get stuffed" (17). Nonetheless, there are noticeable cracks in this façade of efficient policy-making and commitment to the country and its people, caused exactly by those who targeted the audience by (un)subtle manipulations regarding the state of affairs in the United Kingdom. One such character, resembling the current Prime Minister, elucidates their general machinations:

Instead of merely telling lies, we wrote them on a bus! ... The whole of our economy is built on foreign backs/Their doctors and their workers bring us skills the uk lacks. ... "We want our sovereignty!" we cried, with such pious faces/And all the while we palled around with lunatics and racists/How good will independence feel when we're all broke and blue? (67)

What has been outlined above implies the primacy of deceptions and irrationality over sound judgment. In the same vein, Stonebridge analyzed the phenomenon of Brexit, highlighting "the stupidity ..., the easy idiocy that has unleashed ... intolerance, [but also] economic and political instability" (7). In the epilogue to Alice in Brexitland, Lucien writes in the same spirit, noting wryly what his reaction to any political coverage was as follows: "Turning on the B BC/Feels like taking LSD/Breaking news is breaking me/Impotently I despise/ 
Hollow fools with hollow eyes/Bludgeoning the world with lies." His "Post-truth Poem" illustrates the country's future as fraught with peril, and its inhabitants as standing on a precipice. On the other hand, the author is not utterly pessimistic as "Light still penetrates the mist" (101). Nonetheless, whether Englishness eventually will be associated with besieged mindsets, insularity, perversions, or xenophobia remains to be seen.

Taking into account the myriad critical and literary voices analyzed in this paper, it is legitimate to make a cautious claim that some of the expectations people expressed before/during the referendum have proven inflated and deflatedin the post-plebiscite reality. In 2016, across the majority that voted for the divorce, what was seen was a growing consensus on the soundness of pro-Leave arguments about Great Britain being in "a state of emergency" (Heidemann 4). The proponents of change had endorsed the policy of restoring a sense of collective dignity by "protect[ing] traditional national identity ..., often explicitly connected with ethnicity or religion" (Fukuyama 7). That mode of reasoning has been confronted with the "unplanned" turbulence of (re) adjustment, however. The whole process of bidding farewell to the European Union has led to sentiments of uncertainty/anxiety/regret, rather than to the anticipated sense of satisfaction/relief. The main objective of this paper was to ponder over those initial conditions that advocated a return to the past in order to "excavate" the purity of English character/tradition/mindset. Central to achieving this, as many have purported, was a policy of "national quarantine" that was to contain the spread of cultural and political otherness. However, as argued in this study, there is an array of more reflective thoughts and (other) commentaries presented in numerous academic and literary texts, which grasp the idea of a new post-Brexit world in a more critical and alternative manner. The various authors (scholars and writers), speaking of the nostalgia for both a homogenous landscape and an elevated status of Britishness, indicate that the yearning for a grand dimension of national identity may eventually contribute to the emergence of a less dignified, more insular version of Englishness. Hence, the overall picture discernable from the five novels, including the one written several years prior to Brexit, is indeed very Andersonian in character. Each of the novelists weaves a similar story, elaborating on (re)constructions of British/ English identity, and in one way or another attesting to a process of "patriotic self-delusion." ${ }^{23}$ To what extent such literary representations of the advocates of a world of fossilized identities provide lessons for the entire continent remains an open question.

23 See Bradford discussing "English patriots ... as hopelessly self-deluded" (98). 


\section{| Works Cited}

Anderson, Benedict. Imagined Communities. Reflections on the Origin and Spread of Nationalism. London and New York: Verso, 2006.

Aughey, Arthur. "Anxiety and Injustice: The Anatomy of Contemporary English

Nationalism." Nations and Nationalism 16. 3 (2010): 506-524.

Barnes, Julian. England, England. London: Vintage, 2012.

Bauman, Zygmunt. In Search of Politics. Stanford: University Press, 1999.

Berger, Stefan. "A Return to the National Paradigm? National History Writing in Germany, Italy, France, and Britain from 1945 to the Present." The Journal of Modern History 77 (2005): 629-678.

Bilenkyi, Serhii. Romantic Nationalism in Eastern Europe: Russian, Polish, and Ukrainian Political Imaginations. Stanford: University Press, 2012.

Black, Jack. "From Mood to Movement: English Nationalism, the European Union and Taking Back Control." Innovation: The European Journal of Social Science Research 32. 2 (2019): 191-210.

Boyle, Frankie. The Future of British Politics. London: Unbound, 2020.

Bradford, Richard. "Julian Barnes's England, England and Englishness." Julian Barnes: Contemporary Critical Perspectives. Eds. Sebastian Groes and Peter Childs. London: Continuum, 2011: 92-102.

Browning, Christopher. "Brexit Populism and Fantasies of Fulfilment." Cambridge Review of International Affairs 32.3 (2019): 222-244.

Chetty, Darren. "'You Can't Say That! Stories Have to Be About White People"." Good Immigrant. Ed. Nikesh Shukla. London: Unbound, 2017. 96-107.

Cheyette, Bryan. "English Literature Saved My Life." Brexit and Literature. Ed. Robert Eaglestone. Abingdon: Routledge, 2019. 66-72.

Condor, Susan and Steve Fenton. "Thinking across Domains: Class, Nation and Racism in England and Britain." Ethnicities 12. 4 (2012): 385-393.

Craig, Amanda. The Lie of the Land. London: Abacus, 2017.

Cuddon, John Anthony. Penguin Dictionary of Literary Terms. London: Penguin Books, 1992.

de Bourbon-Parme, Tristan. "A Rational Vote Against a Rational Argument? (Or What Was It Really About?)” Do They Means Us? The Foreign Correspondents' View of Brexit. Eds. John Mair and Neil Fowler. Birmingham: University Press, 2019. 30-34.

Docherty, Thomas. "Brexit: Thinking and Resistance." Brexit and Literature. Ed. Robert Eaglestone. Abingdon: Routledge, 2019: 181-195.

Einhaus, Ann-Marie. "Researching Britain and Europe, Then and Now." Brexit and Literature. Ed. Robert Eaglestone. Abingdon: Routledge, 2019: 160-166. 
Fukuyama, Francis. Identity. Contemporary Identity Politics and the Struggle for Recognition. London: Profile Books, 2019.

Galton, Bridget. "Amanda Craig: 'Brexit Is a Lightning Rod for Rural People”.'

3 July 2017, https://tinyurl.com/49kkvw5b. Accessed 29 April 2021.

Hall, Stuart. "Cultural Studies: Two Paradigms." Contemporary Literary Criticism. Literary and Cultural Studies. Eds. Robert Con Davis and Ronald Schleifer, 1998: 663-678.

Heidemann, Birte. “The Brexit Within: Mapping the Rural and the Urban in Contemporary British Fiction." Journal of Postcolonial Writing, 2020: 1-14. Hirsch, Afua. Brit(ish). On Race, Identity and Belonging. London: Vintage, 2018. Hollinghurst, Alan. "A Larger Life." A Love Letter to Europe. An Outpouring of Sadness and Hope from Writers, Thinkers and Artists. Hodder \& Stoughton. Kindle Edition, 2019: Loc. 300-306.

Kapsali, Daphne. Divided Kingdom. How Brexit Made Me an Immigrant. Poland: Amazon Fulfillment, 2016.

McEwan, Ian. The Cockroach. London: Jonathan Cape, 2019.

Mishra, Pankaj. Age of Anger. A History of the Present. London: Penguin Books, 2018.

Nedergaard, Peter and Maja Friis Henriksen. "Brexit and British Exceptionalism." Routledge Handbook of the Politics of Brexit. Eds. Patric Diamond and Peter Nedergaard. London: Routledge, 2018. 134-146.

Said, Edward. "Invention, Memory and Place." Critical Inquiry 26: 2 (2000): 175-192.

Schultz, Bettina. "Did the British Ever Understood Europe? (Or Was It Always Outside Their Immagination?)" Do They Means Us? The Foreign Correspondents' View of Brexit. Eds. John Mair and Neil Fowler. Birmingham: University Press, 2019. 25-29.

Shaw, Kristian. "BrexLit." Brexit and Literature. Ed. Robert Eaglestone. Abingdon: Routledge, 2019. 15-30.

Smith, Ali. Autumn. London: Penguin Books, 2017.

Sobolewska, Maria and Robert Ford. BrexitLand. Cambridge: University Press, 2020.

Stratton, Jon. "The Language of Leaving: Brexit, the Second World War and Cultural Trauma." Journal for Cultural Research 23. 3 (2019): 225-251.

Stonebridge, Lyndsay. “The Banality of Brexit." Brexit and Literature. Ed. Robert Eaglestone. Abingdon: Routledge, 2019. 7-15.

Upstone, Sara. "Do Novels Tell Us How to Vote." Brexit and Literature. Ed. Robert Eaglestone. Abingdon: Routledge, 2019. 44-58.

Wigura, Katarzyna. "Psoty z żukiem.” 16 March 2010, https://tinyurl.com/jbpuf387. Accessed 28 April 2021. 
Wincott, Daniel. "Brexit and the State of the United Kingdom.” Routledge Handbook of the Politics of Brexit. Eds. Patric Diamond and Peter Nedergaard. London: Routledge, 2018. 15-26.

Young, Lucien. Alice in Brexitland. London: Ebury Press, 2017.

\section{| Abstract}

RYSZARD BARTNIK

From Unparalleled “Greatness” to Predictable Insularity. A Composite Sketch of "Warped Britishness" as Drawn in Selected Works of Contemporary English Fiction

Brexit, as seen from the present perspective, is seemingly a success story. Taking into account a myriad of voices expressed in the public domain over the past few years, it is legitimate to make a cautious claim that some of the expectations people shared before/during the referendum have been inflated and deflated in the post-plebiscite reality. In 2016, across the majority that voted for the divorce, a growing consensus on the soundness and solidity of pro-Leave arguments about Britain being in crisis was seen. The proponents of change had endorsed the policy of restoring a sense of national dignity. That mode of reasoning, though still present within current "British" mindsets, has been confronted with the "unplanned" turbulence of national (re) adjustment. The whole process of bidding farewell to the European Union has led to sentiments of uncertainty/anxiety/regret, rather than to the anticipated sense of satisfaction/relief. Therefore, it seems both vital and interesting to juxtapose the passion about restoring people's trust in Britishness/Englishness, and its "exceptionality" with more sobering projections of a new post-Brexit world. In order to discuss the consequences of this self-inflicted condition, I will here elaborate on selected English literary texts. They feature authors who draw conclusions running parallel to Anderson's assumptions that in times of crisis a general predilection for self-deluding (re)constructions of collective identity can be observed, which are variously expressed in a merely referential, subversive or satirical manner.

Keywords: Brexit; Britishness/Englishness; collective identity; insularity; literature after Brexit 


\section{| Abstrakt}

RYSZARD BARTNIK

Od niezrównanej „wielkości” do dającej się przewidzieć zaściankowości. Szkic „wypaczonej brytyjskości” na podstawie wybranych dzieł współczesnej literatury angielskiej

Brexit, widziany z dzisiejszej perspektywy, jest pozornie historią sukcesu. Biorąc pod uwagę wielość głosów wyrażonych w przestrzeni publicznej na przestrzeni ostatnich kilku lat, wydaje się zasadnym stwierdzenie, iż niektóre spośród oczekiwań formułowanych przed/w trakcie referendum uległy inflacji i deflacji w postplebiscytowej rzeczywistości. W 2016 roku w szeregach większości, która głosowała za rozwodem, dało się zauważyć konsensus odnośnie do twierdzenia, iż Brytania jest w kryzysie. Zwolennicy zmiany od dłuższego czasu postulowali wzmocnienie polityki przywracania narodowej godności. Ten sposób rozumowania, choć nadal obecny w umysłach wielu Brytyjczyków, został skonfrontowany z nieplanowanymi turbulencjami narodowego dostrajania się. Cały proces żegnania się z Unią Europejską raczej uwypuklił uczucia niepewności/niepokoju/żalu, niż wzmocnił poczucie satysfakcji czy też ulgi. Dlatego też wydaje się ważne i interesujące, by zestawić zapał dotyczący przywrócenia zaufania do brytyjskości/angielskości, do „wyjątkowości”, z otrzeźwiającymi projekcjami nowej rzeczywistości po brexicie. Konsekwencje narzuconych uwarunkowań zostaną omówione na bazie wybranych angielskich tekstów literackich. Ukazują one autorów, których konkluzje są zbieżne z twierdzeniem Andersona, iż w czasie kryzysu daje się zaobserwować ogólną skłonność do zwodniczych (re)konstrukcji tożsamości zbiorowej, czemu twórcy dali wyraz w tekstach o czysto referencyjnym, czasami prześmiewczo-subwersywnym, a w innym przypadku czysto satyrycznym charakterze.

Słowa kluczowe: brexit; brytyjskość/angielskość; tożsamość zbiorowa; zaściankowość; literatura po brexicie

\section{| About the Author}

Dr hab. Ryszard Bartnik works as a tenured professor at Adam Mickiewicz University, in Poznań [Department of Literary Studies and Literary Linguistics]. As a teacher and academic, with expertise in the area of contemporary British/English/ Northern Irish fiction, he specializes in studying correlations between novelistic writing and socio-political narratives. He is particularly interested in literary 
thematizations of such phenomena as 'trauma', 'memory', 'violence, 'reconciliation', 'divided societies' or 'fundamentalist thought/ideology'. His very recent book, published in 2017, was devoted to post-apartheid South African and post-Troubles Northern Irish literary narratives, and the ways their authors tried to discuss/heal the wounds of the past. Dr Bartnik's current scholarly interests have been slightly shifted to focus on how British 'new journalism,' 'literary [non-]fiction', or socio-political discourse attempt to tackle the question/problem of Brexit.

E-mail: rbartnik@amu.edu.pl

ORCID: 0000-0002-3675-0650 